\title{
Aboveground biomass, productivity and carbon sequestration in Rhizophora stylosa mangrove forest of Southeast Sulawesi, Indonesia
}

\author{
KANGKUSO ANALUDDIN ${ }^{1, \bullet}$, LA ODE KADIDAE ${ }^{2}$, LA ODE MUHAMMAD YASIR HAYA ${ }^{3}$, ANDI SEPTIANA ${ }^{1}$, \\ IDIN SAHIDIN ${ }^{4}$, LA SYAHRIR ${ }^{5}$, SABAN RAHIM ${ }^{6}$, LA ODE ABDUL FAJAR ${ }^{7}$, KAZUO NADAOKA $^{8}$ \\ ${ }^{1}$ Biotechnology Program, Mathematics and Natural Sciences, Universitas Halu Oleo. Jl. HEA Mokodompit, Kendari 93232, Southeast Sulawesi, \\ Indonesia. Tel. +62-401-3191929, `email: zanzarafli@gmail.com \\ ${ }^{2}$ Chemistry Program, Mathematics and Natural Sciences, Universitas Halu Oleo. J1. HEA Mokodompit, Kendari 93232, Southeast Sulawesi, Indonesia \\ ${ }^{3}$ Marine Science Program, Faculty of Fisheries and Marine Sciences, Universitas Halu Oleo. Jl. HEA Mokodompit, Kendari 93232, Southea st Sulawesi, \\ Indonesia \\ ${ }^{4}$ Faculty of Pharmacy, Universitas Halu Oleo. Jl. HEA Mokodompit, Kendari 93232, Southeast Sulawesi, Indonesia \\ ${ }^{5}$ Fisheries Science Postgraduate Program, Universitas Halu Oleo. Jl. HEA Mokodompit, Kendari 93232, Southeast Sulawesi, Indonesia \\ ${ }^{6}$ Geography Program, Faculty of Earth Science and Technology, Universitas Halu Oleo. Jl. HEA Mokodompit, Kendari 93232, Southeast Sulawesi, \\ Indonesia \\ ${ }^{7}$ Marine Science Program, Universitas Sembilanbelas November. Jl. Pemuda, Tahoa, Kabupaten Kolaka 93561, Sulawesi Tenggara, Indonesia \\ ${ }^{8}$ Department of Transdisciplinary Science and Engineering, School of Environment and Society, Tokyo Institute of Technology. I4-21, 2-12-1 \\ Ookayama, Meguro-ku, Tokyo 152-8552, Japan
}

Manuscript received: 25 November 2019. Revision accepted: 6 March 2020.

\begin{abstract}
Analuddin K, Kadidae LO, Haya LOMY, Septiana A, Sahidin I, Syahrir L, Rahim S, Fajar LOA, Nadaoka K. 2020. Aboveground biomass, productivity and carbon sequestration in Rhizophora stylosa mangrove forest of Southeast Sulawesi, Indonesia. Biodiversitas 21: 1316-1325. This study was aimed at analyzing the trends of aboveground biomass (AGB), productivity and carbon sequestration of Rhizophora stylosa Griff. forest in Rawa Aopa Watumohai National Park (RAWNP), Southeast Sulawesi, Indonesia. The DBH was the best predictor for partial and whole AGB of $R$. stylosa trees. The mean AGB was 562.76 ton ha ${ }^{-1}$. The yearly biomass increment of living trees, biomass increment of whole stands, standing dead biomass, and litterfall in $R$. stylosa forest were estimated as 52.87, 50.09, 2.78 and 12.00 ton $\mathrm{ha}^{-1}$, respectively, while its net primary production was about 64.88 ton ha $^{-1} \mathrm{yr}^{-1}$ indicating higher mangrove productivity. The total carbon stock in $R$. stylosa forest was 264.50 ton ha ${ }^{-1}$, while the annual net carbon budget, carbon gain and carbon input in $R$. stylosa forest was $23.54,24.85$ and 5.64 ton ha ${ }^{-1}$. However, the total $\mathrm{CO}_{2}$ stored in $R$. stylosa forest was 969.83 ton ha ${ }^{-1}$, while the annual of net $\mathrm{CO}_{2}$ uptake, $\mathrm{CO}_{2}$ gained and $\mathrm{CO}_{2}$ input was $86.33,91.12$ and 20.86 ton ha ${ }^{-1}$. The higher carbon sequestration and $\mathrm{CO}_{2}$ uptake in $R$. stylosa forest indicate its significant role in the global carbon accumulation and reducing atmospheric $\mathrm{CO}_{2}$.
\end{abstract}

Keywords: Carbon sequestration, carbon stock, mangrove biomass, mangrove productivity, Rhizophora stylosa forest

\section{INTRODUCTION}

Mangroves play an important role as source of carbon and nutrients in the coastal area (Clough 1992, 1998; Twilley et al, 1992; 1995). The mangroves are known to sequestrate organic matter and are capable of accumulating and storing carbon and nutrients in the soil (Spalding et al. 2010). Several studies have mentioned the mangrove litterfall as a major source of organic matter and nutrients for adjacent coastal areas (Twilley 1998; Alongi and Dixon 2000). Large amounts of mangrove litter are the most important sources of food and energy for all living organisms in coastal ecosystem (Hoque at 2015; Kristensen and Suraswadi 2002). Mangrove litter may enter into the rivers and streams when rain or tides inundate the forest, and decompose either in the source forest or in the river, with nutrients being retained or exported (Conacher et al. 1996).

High rate of primary production of mangroves has been verified on the coastlines, and biomass and productivity of mangroves are the two important parameters for elucidating the material and nutrient inputs in the mangrove ecosystem (Sherman et al 2003). Many studies have developed the biomass estimation methods for mangroves such as harvest method, mean-tree method and allometric method (Golley et al. 1975; Ketterings et al. 2001). The allometric method is the most frequently used method for estimating the mangrove forests biomass from measurable tree dimensions (Clough and Son 1989; Clough 1997, Komiyama et al. 2005, 2008; Mahmood et al. 2004, 2012). Meanwhile, allometric models for biomass estimation vary greatly among the species and sites, even in the mangroves grown in the same region (Analuddin et al. 2016b, 2018; Komiyama et al. 2008). Therefore, Ketterings et al. (2001) mentioned that it is preferable to use species and sitespecific models for biomass estimation. Many allometric studies for mangroves biomass estimation have been reported (Deshar et al. 2012; Mahmood et al. 2012; Siddique et al. 2012). In some recent reports, allometric models and biomass estimation have been studied for mangroves growing in coral triangle ecoregion (Analuddin et al. 2016b, 2018). 
Mangrove is one among the important coastal ecosystems in the coral triangle ecoregion Southeast Sulawesi, which play a very important role as a biofilter of heavy metals pollutants (Analuddin et al. 2017). Therefore, the mangroves maintain the health of coastal and marine ecosystems in coral triangle ecoregion. Although several studies in the coral triangle areas on mangroves allometric models and their biomass estimation (Analuddin et al 2016b, 2018), mangrove bioprospecting (Septiana et al. 2016; Analuddin et al. 2019) as well as the mangrove blue carbon stock (Analuddin et al. 2016a) have been undertaken so far, meager information is available regarding productivity and carbon sequestration of mangrove forests of this region. Therefore, the current study was undertaken in the coral triangle ecoregion, i.e. Rawa Aopa Watumohai National Park (RAWNP), Southeast Sulawesi, Indonesia with the objectives of estimation of aboveground biomass and productivity of Rhizophora stylosa mangrove forest, and elucidation of its carbon stock and carbon sequestration.

\section{MATERIALS AND METHODS}

\section{Study site}

This study was carried out at the mangrove forest of Rawa Aopa Watumohai National Park (RAWNP) of coral triangle ecoregion, Southeast Sulawesi, Indonesia (Figure 1 ), which is located at the eastern part of Kendari city (S: 04'33'12.1" and E: $\left.122^{\circ} 0.3^{\prime} 20.4^{\prime \prime}\right)$. The mangrove tree species Rhizophora stylosa Griff. (Rhizophoraceae) has limited distribution in the coral triangle ecoregion. Its growth is restricted to the protected areas, but it was rarely present in unprotected areas. $R$. stylosa grows mostly in the soft muddy sites of the RAWNP (Analuddin et al. 2013). Mangroves at protected areas of Southeast Sulawesi, including RAWNP, have been recognized as an important conservation area and habitat for the endemic animal Bubalus sp. (Septiana et al. 2016).
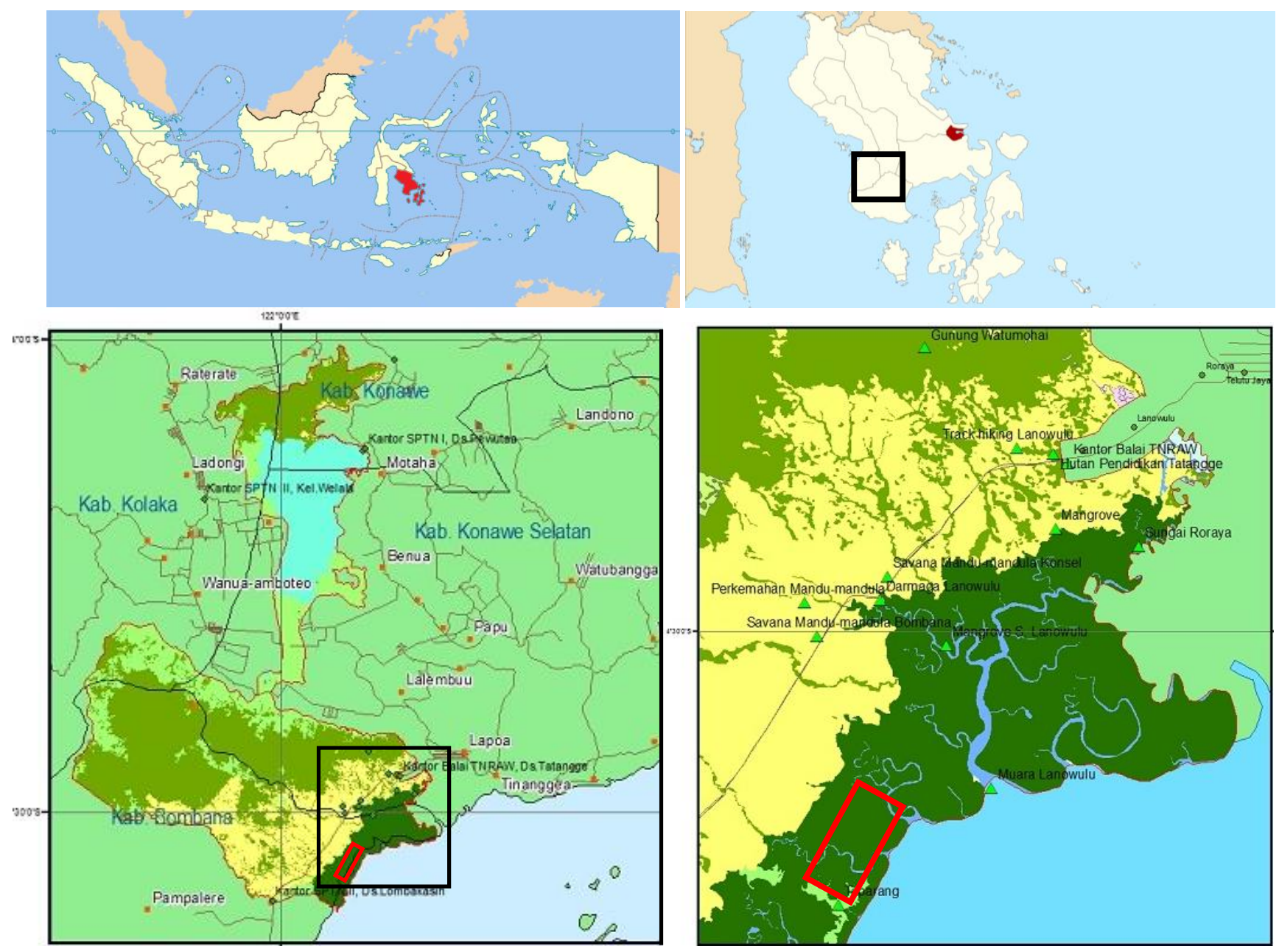

Figure 1. Map of mangrove forest of Rawa Aopa Watumohai National Park in Southeast Sulawesi, Indonesia (S: 04³3'12.1" and E: $\left.122^{\circ} 0.3^{\prime} 20.4^{\prime \prime}\right)$. Red box: study location (Rhizophora stylosa forest) 


\section{Procedures}

Sampling for allometric models

Allometric models were established by selecting eight individual trees in different size classes of Rhizophora stylosa. All selected trees were harvested, and divided into main stem, branch/twig, leaf as well as prop root components. The main stem was cut into pieces of $1 \mathrm{~m}$ length, from the base to the top. All fresh weight of tree components were measured of their weight at the sample plot. About $10 \mathrm{~cm}$ sized discs were cut from each $1 \mathrm{~m}$ length main stem segments and taken together with branches/twigs, prop roots and leaves to the Biology Laboratory at Halu Oleo University. Samples were ovendried to $80^{\circ} \mathrm{C}$ until mass remains constant. The dry mass of Rhizophora stylosa trees parts (stem, branch/twig, leaf and prop roots) were estimated as dry/fresh biomass ratios (Brown et al. 1997).

\section{Sampling for biomass and productivity}

Analysis of biomass and productivity of Rhizophora stylosa forest was carried out by marking 3 permanent plots, each of $300 \mathrm{~m}^{2}$ wide. All individual trees in each plot were numbered, and tree census was conducted during 2014 and 2015. The stem diameter at breast height (DBH) was measured in the entire plot, using diameter tape. In addition, the litterfalls were collected from March 2014 to February 2015 by using 15 net traps (circle net trap with $0.5 \mathrm{~cm}$ of mouth diameter, and $1 \mathrm{~mm}$ mesh). The net traps were put $1.5 \mathrm{~m}$ above soil, while monthly litterfalls were collected at the end of every month. The litterfalls were collected in plastic bags and brought to the laboratory, and sorted according to leaf, branch/twig, and reproductive parts. Each litterfall part then placed in envelopes, dried at $80^{\circ} \mathrm{C}$ for two days, and then weighted separately.

\section{Data analysis}

\section{Allometric models equations}

Allometric models for estimation of stem weight $w_{\mathrm{S}}$, branch weight $w_{\mathrm{B}}$, leaf weight $w_{\mathrm{L}}$ and prop root weight $w_{\mathrm{R}}$ of Rhizophora stylosa trees were established using independent variables $\mathrm{D}_{30}, \mathrm{DBH}, \mathrm{D}_{30}{ }^{2} \mathrm{H}$ and $\mathrm{DBH}^{2} \mathrm{H}$. The equation forms were developed by using the method of Khan et al. (2018). The allometric models for estimation of $w_{\mathrm{S}}, w_{\mathrm{B}}, w_{\mathrm{L}}$ and $w_{\mathrm{R}}$ of $R$. stylosa trees were developed in the form of equations of one and two dimensions, as follows:

$$
\begin{aligned}
& \mathrm{w}_{S}=a_{0} D_{30}{ }^{\mathrm{a} l} \\
& \mathrm{w}_{S}=a_{0} D_{B H^{\mathrm{a}} l} \\
& \mathrm{w}_{S}=a_{0}\left(D_{30}^{2} \times H\right)^{\mathrm{a} l} \\
& \mathrm{w}_{S}=a_{0}\left(D_{B H^{2}} \times H\right)^{\mathrm{a} l} \\
& \mathrm{w}_{B}=b_{0} D_{30}^{\mathrm{b} l} \\
& \mathrm{w}_{B}=b_{0} D_{B H^{\mathrm{b}}}{ }^{\mathrm{b}} \\
& \mathrm{w}_{B}=b_{0}\left(D_{30}^{2} \times H\right)^{\mathrm{b} I} \\
& \mathrm{w}_{B}=b_{0}\left(D_{B H^{2}} \times H\right)^{\mathrm{b} l} \\
& \mathrm{w}_{L}=c_{0} D_{30}{ }^{\mathrm{c} l} \\
& \mathrm{w}_{L}=c_{0} D_{B H}{ }^{\mathrm{c} l} \\
& \mathrm{w}_{L}=c_{0}\left(D_{30}{ }^{2} \times H\right)^{\mathrm{c} l} \\
& \mathrm{w}_{L}=c_{O}\left(D_{B H^{2}} \times H\right)^{\mathrm{c} l} \\
& \mathrm{w}_{R}=t_{0} D_{30}{ }^{\mathrm{t} l} \\
& \mathrm{w}_{R}=t_{0} D_{B H^{\mathrm{t}}}{ }^{\mathrm{w}} \\
& \mathrm{w}_{R}=t_{0}\left(D_{30}{ }^{2} \times H\right)^{\mathrm{tl}}
\end{aligned}
$$

$\mathrm{w}_{R}=t_{0}\left(D_{B H}{ }^{2} \times H\right)^{\mathrm{t} l}$

Where; $\mathrm{D}_{30}$ is stem diameter at $30 \mathrm{~cm}$ from the ground, $\mathrm{DBH}$ is stem diameter at breast height $(1.3 \mathrm{~m}$ from the ground), $\mathrm{H}$ is tree height, while the $c, a, b, t$ are parameters. The values of $c, a, b, t$ and coefficient determination $\mathrm{R}^{2}$ for all allometric equations were estimated by least square method.

\section{Partial and whole biomass estimation}

The total stem biomass $w_{\mathrm{S}}$, total branch biomass $w_{\mathrm{B}}$, total leaf biomass $w_{\mathrm{L}}$ and total prop root biomass $w_{\mathrm{R}}$ of $R$. stylosa trees in each stand was estimated by summation method using the equations of Analuddin et al. (2016b) as follows:

$$
w_{\mathrm{S}}=\sum_{i=1}^{n} w_{\mathrm{S} 1}+w_{\mathrm{S}_{2}}+\ldots . w_{\mathrm{S}_{n}}
$$

Where; $w_{\mathrm{S}}$ is individuals stem weight of mangrove trees.

$$
w_{\mathrm{B}}=\sum_{i=1}^{n} w_{\mathrm{B} 1}+w_{\mathrm{B} 2}+\ldots . w_{\mathbf{B}_{n}}
$$

Where; $w_{\mathrm{B}}$ is individuals branch weight of mangrove trees.

$$
w_{\mathrm{L}}=\sum_{i=1}^{n} w_{\mathrm{L} 1}+w_{\mathrm{L} 2}+\ldots . w_{\mathrm{L} n}
$$

Where; $w_{\mathrm{L}}$ is individuals leaf weight of mangrove trees.

$$
w_{\mathrm{R}}=\sum_{i=1}^{n} w_{R 1}+w_{\mathrm{R} 2}+\ldots . w_{\mathrm{R}_{n}}
$$

Where; $w_{\mathrm{R}}$ is individuals prop root weight of $R$. stylosa trees.

Total aboveground biomass $w$ of $R$. stylosa in each stand was estimated by summation method using the following equation:

$$
w=\sum w_{\mathrm{S}}+\sum w_{\mathrm{B}}+\sum w_{\mathrm{L}}+\sum w_{\mathrm{R}}
$$

\section{Mangrove productivity analysis}

The productivity of $R$. stylosa mangrove was estimated including biomass increment, standing dead biomass, litterfall, and net primary production. The biomass increment for living $R$. stylosa trees, $\Delta y^{\prime}$ is estimated by using the following equation of Kira and Shidei (1967) as follows:

$\Delta y^{\prime}=\left\{\left(\sum_{i=1}^{n} w_{\mathrm{T} 2.1}+w_{\mathrm{T} 2.2}+w_{\mathrm{T} n . m}\right)-\left(\sum_{i=1}^{n} w_{\mathrm{T} 1.1}+w_{\mathrm{T} 1.2}+w_{\mathrm{T} n . m}\right)\right\}$

Where; $w_{\mathrm{T} 2.1}$ is the plant biomass at second harvest and $\mathrm{W}_{\mathrm{T} 1.1}$ is the plant biomass at the first harvest, while $w_{\text {Tn.m }}$ is the plant biomass for the other time harvest. In addition, standing dead biomass was estimated by summation of individuals' dead biomass, $D$ from the permanent plots. Biomass increment of whole stand, $\Delta y$ is estimated by using the following equation:

$$
\Delta \mathrm{y}=\Delta \mathrm{y}^{\prime}-\mathrm{D}
$$


The aboveground net primary production $\Delta P_{\mathrm{n}}$ was estimated by summation method (Kira and Shidei 1967) of the annual rate of biomass increment of living trees $\Delta y$ and litterfall $\Delta L$ as follows:

$$
\Delta \mathrm{P}_{\mathrm{n}}=\Delta \mathrm{y}+\Delta \mathrm{L}
$$

\section{Carbon stock and $\mathrm{CO}_{2}$ uptake analysis}

The carbon stock in partial and whole aboveground biomass was estimated following the method of IPCC (2006) as follows:

$$
\mathrm{C}=B \times 0.47
$$

Where; $\mathrm{C}$ is carbon stock, $\mathrm{B}$ is biomass and the 0.47 is constant value of $\mathrm{C}$ in organic matter (IPCC 2006).

The $\mathrm{CO}_{2}$ uptake in mangrove tissues was obtained by conversion of carbon stock to $\mathrm{CO}_{2}$ that use the molecular relative mass of $\mathrm{CO}_{2}(44)$ to the relative atomic mass ratio of $\mathrm{C}$ (12) following the method of Hidayah and Andriani (2019) as follows:

$$
W \mathrm{CO}_{2}=\mathrm{C}_{\mathrm{n}} *\left(\mathrm{Mr} . \mathrm{CO}_{2} / \mathrm{Ar} . \mathrm{C}\right)
$$

Where; $W \mathrm{CO}_{2}$ is $\mathrm{CO}_{2}$ absorption, $\mathrm{Mr}$ is molecular relative (44), $\mathrm{Ar}$ is atomic relative (12) and $\mathrm{Cn}$ is carbon stock.

\section{RESULTS AND DISCUSSION}

\section{Allometric models of biomass}

Table 1 represents the allometric models of partial and whole aboveground mass of Rhizophora stylosa trees. The allometric models of stem biomass $w_{\mathrm{S}}$, branch biomass $w_{\mathrm{B}}$, leaf biomass $w_{\mathrm{L}}$, prop root weight $w_{\mathrm{R}}$ and aboveground biomass $w$ of $R$. stylosa trees were established using independent variables $\mathrm{D}_{30}, \mathrm{DBH}$ and quadratic parameters with tree height $\mathrm{H}\left(\mathrm{D}_{30}{ }^{2} \mathrm{H}, \mathrm{DBH}^{2} \mathrm{H}\right)$. The constant values of $a_{0}$ and $a_{1}$ from allometric equations of $w_{\mathrm{S}}$ for $R$. stylosa trees were estimated as $3.15 \times 10^{-2}$ and $3.04\left(R^{2}=0.935\right)$ for $\mathrm{D}_{30}, 3.79 \times 10^{-2}$ and $3.04\left(R^{2}=0.948\right)$ for $\mathrm{DBH}, 0.74 \times$ $10^{-2}$ and $1.21\left(R^{2}=0.963\right)$ for $\mathrm{D}_{30}{ }^{2} \mathrm{H}$ and $0.91 \times 10^{-2}$ and $1.20\left(R^{2}=0.967\right)$ for $\mathrm{DBH}^{2} \mathrm{H}$, respectively. It seems that independent variables $\mathrm{D}_{30}{ }^{2} \mathrm{H}$ and $\mathrm{DBH}^{2} \mathrm{H}$ are more appropriate for estimating stem mass of $R$. stylosa trees. Meanwhile, the values of $b_{0}$ and $b_{1}$ from allometric equations of $w_{\mathrm{B}}$ for $R$. stylosa trees were estimated as 1.6 $\times 10^{-1}$ and $1.9\left(R^{2}=0.983\right)$ for D30, $1.8 \times 10^{-1}$ and $1.9\left(R^{2}=\right.$ $0.991)$ for $\mathrm{DBH}, 6.65 \times 10^{-2}$ and $0.749\left(R^{2}=0.973\right)$ for $\mathrm{D} 30^{2} \mathrm{H}$ and $7.5 \times 10^{-2}$ and $0.745\left(R^{2}=0.974\right)$ for $\mathrm{DBH}^{2} \mathrm{H}$, respectively. Thus, independent variables $\mathrm{D}_{30}$ and $\mathrm{DBH}$ are more precise for estimating the $w_{\mathrm{B}}$ of $R$. stylosa trees. However, the values of $c_{0}$ and $c_{1}$ from allometric equations of $w_{\mathrm{L}}$ in $R$. stylosa trees were estimated as $6.66 \times 10^{-2}$ and $1.82\left(R^{2}=0.96\right)$ for $\mathrm{D}_{30}, 7.49 \times 10^{-2}$ and $1.81\left(R^{2}=0.96\right)$ for DBH, $2.76 \times 10^{-2}$ and $0.725\left(R^{2}=0.98\right)$ for $\mathrm{D}_{30}{ }^{2} \mathrm{H}$ and $3.16 \times 10^{-2}$ and $0.718\left(R^{2}=0.969\right)$ for $\mathrm{DBH}^{2} \mathrm{H}$, respectively. It means that $\mathrm{D}_{30}{ }^{2} \mathrm{H}$ is the best independent variable for estimating $w_{\mathrm{L}}$ of $R$. stylosa trees. Meanwhile, the values of $t_{0}$ and $t_{1}$ from allometric equations of prop root biomass $\left(w_{\mathrm{R}}\right)$ in $R$. stylosa trees were estimated as 8.99 $\times 10^{-2}$ and $2.53\left(R^{2}=0.95\right)$ for $\mathrm{D}_{30}, 1.07 \times 10^{-1}$ and $2.51\left(R^{2}\right.$ $=0.96)$ for $\mathrm{DBH}, 3.94 \times 10^{-2}$ and $0.97\left(R^{2}=0.94\right)$ for $\mathrm{D}_{30}{ }^{2} \mathrm{H}$ and $4.16 \times 10^{-2}$ and $0.96\left(R^{2}=0.944\right)$ for $\mathrm{DBH}^{2} \mathrm{H}$, respectively. Thus, the independent variable $\mathrm{DBH}$ is the best predictor of prop root biomass $w_{\mathrm{R}}$ of $R$. stylosa trees. Although, various independent variables are applicable for estimation of partial and whole aboveground biomass of $R$. stylosa trees, the DBH is the best parameter for biomass estimation due to its easy measurement in the field.

In comparison with allometric models of mangroves from previous studies (Table 2), the allometric models of $R$. stylosa trees seemed to show different trends as compared with allometric models of several mangrove species grown at the same region (Analuddin et al. (2016b, 2018). Allometric models of stem weight, branch weight and leaf weight of $L$. racemosa trees well fitted with independent variables of $\mathrm{DBH}^{2} \mathrm{H}, \mathrm{DB}$, and $\mathrm{DBH}$, respectively, though DBH could be also applied (Analuddin et al. 2016b). Similarly, allometric models of branch weight and leaf weight of $R$. apiculata trees fitted well to independent variable $\mathrm{DBH}$, while it stems weight well fitted to the independent variable of D30 (Analuddin et al. 2018). Furthermore, they also found that allometric models of partial and whole aboveground mass of $R$. mucronata trees fitted well to independent variables of $\mathrm{DBH}^{2} \mathrm{H}$, though $\mathrm{DBH}$ could be also applied. Same authors also found that allometric models of partial and whole aboveground biomass of Ceriops tagal were well fitted with independent variable of D30, though DBH could be also applied.

\begin{tabular}{|c|c|c|c|c|}
\hline \multirow{2}{*}{$\begin{array}{c}\text { Independent } \\
\text { variables }\end{array}$} & \multirow{2}{*}{$\begin{array}{c}\text { Dependent } \\
\text { variables }\end{array}$} & \multicolumn{2}{|c|}{ Coefficient values } & \multirow{2}{*}{$\begin{array}{c}\begin{array}{c}R^{2} \\
\text { values }\end{array} \\
R^{2}\end{array}$} \\
\hline & & $a_{0}$ & $a_{1}$ & \\
\hline$D_{30}$ & Stem mass $w_{\mathrm{s}}$ & 0.031493 & 3.0405 & 0.935 \\
\hline$D_{\mathrm{BH}}$ & & 0.0379 & 3.0382 & 0.948 \\
\hline$D_{30}^{2} H$ & & 0.007372 & 1.2114 & 0.963 \\
\hline $\mathrm{DBH}^{2} H$ & & 0.009127 & 1.201 & 0.967 \\
\hline$D_{30}$ & Branch/twig & $b_{0}$ & $b_{1}$ & $\mathbf{R}^{2}$ \\
\hline$D_{\text {BH }}$ & mass $w_{\mathrm{B}}$ & 0.1577 & 1.8956 & 0.983 \\
\hline$D_{30}{ }^{2} H$ & & 0.17488 & 1.8995 & 0.991 \\
\hline \multirow[t]{2}{*}{$\mathrm{D}_{\mathrm{BH}^{2}}{ }^{H}$} & & 0.066485 & 0.7492 & 0.973 \\
\hline & & 0.074992 & 0.7445 & 0.974 \\
\hline$D_{30}$ & Leaf mass $w \mathrm{~s}$ & $c_{0}$ & $c_{1}$ & $\mathbf{R}^{2}$ \\
\hline$D_{\mathrm{BH}}$ & & 0.066595 & 1.8148 & 0.960 \\
\hline$D_{30}{ }^{2} H$ & & 0.074973 & 1.8098 & 0.957 \\
\hline \multirow[t]{2}{*}{$\mathrm{DBH}^{2} H$} & & 0.027589 & 0.7251 & 0.975 \\
\hline & & 0.031596 & 0.7178 & 0.969 \\
\hline$D_{30}$ & Prop root & $t_{0}$ & $t_{1}$ & $R^{2}$ \\
\hline$D_{\text {BH }}$ & $\operatorname{mass} w_{\mathrm{R}}$ & 0.089946 & 2.5251 & 0.945 \\
\hline$D_{30}^{2} H$ & & 0.10695 & 2.5143 & 0.960 \\
\hline \multirow[t]{2}{*}{$\mathrm{D}_{\mathrm{BH}}^{2} H$} & & 0.039412 & 0.9705 & 0.940 \\
\hline & & 0.041556 & 0.9596 & 0.944 \\
\hline
\end{tabular}

Table 1. The allometric equations for estimation of partial weights of Rhizophora stylosa trees 
Table 2. Allometric equations for estimation of aboveground biomass of various mangroves based on $\mathrm{D}_{\mathrm{BH}}$

\begin{tabular}{|c|c|c|}
\hline Mangroves & Allometric equations & References \\
\hline Lumnitzera racemosa & Wtop $=0.184 D_{\mathrm{BH}^{2.384}} R=0,98, \mathrm{n}=8$ & Analuddin et al. (2016b) \\
\hline Rhizophora apiculata & Wtop $=0.268 D_{\mathrm{BH}^{2.345}} R=0,93, \mathrm{n}=8$ & Analuddin et al. (2018) \\
\hline Rhizophra mucronata & Wtop $=0.143 D_{\mathrm{BH}^{2.519}} R=0,97, \mathrm{n}=8$ & Analuddin et al. (2018) \\
\hline Avicennia germinans & Wtop $=0.140 D$ BН $^{2.40} R=0.97, \mathrm{n}=45$ & Fromard et al. (1998) \\
\hline Avicennia marina & Wtop $=0.308 D_{\text {BH }^{2.11}} R=0.97, \mathrm{n}=22$ & Comley and McGuinness (2005) \\
\hline Laguncularia racemosa & Wtop $=0.102 D_{\mathrm{BH}^{2.50}} R=0.97, \mathrm{n}=70$ & Fromard et al. (1998) \\
\hline Rhizophora apiculata & Wtop $=0.235 \mathrm{DBH}^{2.42} R=0.98, \mathrm{n}=57$ & Ong et al. (2004) \\
\hline Bruguiera gymnorrhiza & Wtop $=0.186 \mathrm{DBH}^{2.31} R=0.99, \mathrm{n}=17$ & Clough and Scott (1989) \\
\hline Ceriops australis & Wtop $=0.189 D_{\mathrm{BH}^{2.34}} R=0.99, \mathrm{n}=26$ & Clough and Scott (1989) \\
\hline Xylocarpus granatum & Wtop $=0.0823 D_{\mathrm{BH}^{2}}{ }^{2.59} R=0.99, \mathrm{n}=15$ & Clough and Scott (1989) \\
\hline Rhizophora stylosa & Wtop $=0.1579 D_{\mathrm{BH}^{2.593}} R=0,98, \mathrm{n}=8$ & Present study \\
\hline
\end{tabular}

Therefore, the consideration of different independent variables for estimation of partial aboveground biomass of mangroves is needed because the mangroves grown at the same region prefer different independent variables as the best predictor for estimation of partial or whole aboveground mass even when the parts mass, such as stem mass or branch, is same. These differences in the applicability of independent variables of allometric models among species might be indicative of the differences in their biological adaptation mechanisms for growth and withstanding various environmental circumstances. Several previous studies (Clough 1992; Steinke et al.1995) mentioned that the coefficient values of allometric models for the same species may vary with localities and it depends on-site quality, tree density, as well as species composition.

However, Komiyama et al. (2005) proposed a common allometric biomass model of mangroves by using $\mathrm{DBH}$, though this allometric model is not applicable for $E$. agallocha trees as their DBH were less than $5 \mathrm{~cm}$. Meanwhile, Mahmood et al. (2004) suggested the differences of coefficients in allometric models for estimation of aboveground biomass of mangroves. Many previous studies found suitability of independent variable $\mathrm{DBH}$ for estimation of aboveground biomass of various mangroves, including Rhizophora apiculata and $R$. mucronata (Analuddin et al. 2018), Lumnitzera racemosa (Analuddin et al. 2016b), Avicennia germinans and Laguncularia racemosa (Fromard et al. 1998), Avicennia marina (Comley and McGuinness 2005), R. apiculata (Ong et al. 2004), Bruguiera gymnorrhiza, Ceriops australis and Xylocarpus granatum (Clough and Scott 1989). Therefore, although different independent variables could be applied for calculating partial or whole aboveground biomass of $R$. stylosa trees, DBH and D30 are the two appropriate and easily measurable parameters. This is because tree height measurement is difficult in the field, though the $\mathrm{DBH}^{2} \mathrm{H}$ well fitted.

\section{Trends of partial and whole aboveground biomass}

Table 3 shows the trends of partial and whole aboveground biomass of $R$. stylosa forest growing in
Southeast Sulawesi. The first-year partial biomass calculation of $R$. stylosa stands showed that stem biomass ranges from 196.91 to 336.63 ton ha ${ }^{-1}$ (average of 248.98 ton $\mathrm{ha}^{-1}$ ), branch biomass ranges 54.23 to 73.15 ton ha ${ }^{-1}$ (average of 61.88 ton $\mathrm{ha}^{-1}$ ), leaf biomass ranges from 18.71 to 24.77 ton $\mathrm{ha}^{-1}$ (average of 21.19 ton $\mathrm{ha}^{-1}$ ), and prop root biomass ranges 149.78 to 230.01 ton ha $^{-1}$ ( average of 180.61 ton $\mathrm{ha}^{-1}$ ). The whole aboveground biomass of $R$. stylosa stands at the first year ranges from 419.64 to 664.55 ton $\mathrm{ha}^{-1}$ (average of 512.65 ton ha ${ }^{-1}$ ).

The second-year partial biomass calculation of $R$. stylosa stands showed that stem biomass ranges from 216.27 to 371.65 ton $\mathrm{ha}^{-1}$ (average of 277.24 ton $\mathrm{ha}^{-1}$ ), branch biomass ranges 57.16 to 76.89 ton ha $^{-1}$ (average of 65.88 ton $\mathrm{ha}^{-1}$ ), leaf biomass ranges from 19.89 to 25.791 ton $\mathrm{ha}^{-1}$ (average of 22.45 ton $\mathrm{ha}^{-1}$ ), and prop root biomass ranges 161.36 to 248.48 ton ha $^{-1}$ (average of 197.19 ton ha ${ }^{1}$ ). The whole aboveground biomass ranges from 454.45 to 722.92 ton ha ${ }^{-1}$ (average 562.76 ton ha ${ }^{-1}$ ).

Aboveground biomass (AGB) of $R$. stylosa forest was much higher than $\mathrm{AGB}$ of various mangroves from different regions of the world (Table 4). The AGB of $R$. stylosa forest was much higher than AGB of $R$. mangle forest in Dominican (Sherman et al. 2003), Florida (Ross et al. 2001) and Mexico (Day et al. 1997). It was also much higher than that of Rhizophora mucronata and Bruguiera gymnorrhiza forests (Suzuki and Tagawa (1993), Kandelia obovata forest in Okinawa Japan and Kandelia candel forest in Hong Kong (Lee 1990). Similarly, the AGB of $R$. stylosa forest was much higher than that of $R$. apiculata (Putz and Chan 1986), R. stylosa forest (Chandra et al. (2011) and B. parviflora forest (Hossein et al. (2008) of Malaysia. In addition, AGB of $R$. stylosa was much higher than AGB of Rhizophora sp. in Thailand (Komiyama et al. 2000) as well as Oligohaline mangrove in Sundarbans, Bangladesh (Kamaruzzaman et al. 2017). The AGB of $R$. stylosa forest was much higher than that of L. racemosa forest (Analuddin et al. 2016b) and $R$. mucronata forest (Analuddin et al. 2018) growing in the same locations in Southeast Sulawesi, although it was lower as compared to AGB of $R$. apiculata forest of the protected area in Southeast Sulawesi (Analuddin et al. 2018). 
Table 3. Trends of stem biomass $w_{\mathrm{s}}$, branch/twig biomass $w_{\mathrm{B}}$, leaves biomass $w_{\mathrm{L}}$, prop root biomass $w_{\mathrm{R}}$ and whole aboveground biomass $w$ of Rhizophora stylosa stands from two-year censuses

\begin{tabular}{|c|c|c|c|c|c|c|}
\hline Years & Stands & $\begin{array}{l}w_{\mathrm{S}} \\
\left(\text { ton } \mathbf{h a}^{-1}\right)\end{array}$ & $\left.\begin{array}{l}w_{B} \\
(\text { ton ha } \\
-1\end{array}\right)$ & $\begin{array}{l}w_{\mathrm{L}} \\
\left(\text { ton } \mathbf{h a}^{-1}\right)\end{array}$ & $\begin{array}{l}w_{\mathrm{R}} \\
\left(\text { ton } \mathbf{h a}^{-1}\right)\end{array}$ & $\begin{array}{l}w \\
\left(\text { ton } h^{-1}\right)\end{array}$ \\
\hline \multirow[t]{5}{*}{2014} & 1 & 336.63 & 73.15 & 24.77 & 230.01 & 664.55 \\
\hline & 2 & 213.40 & 58.25 & 20.07 & 162.02 & 453.75 \\
\hline & 3 & 196.91 & 54.23 & 18.72 & 149.78 & 419.64 \\
\hline & Average & 248.98 & 61.88 & 21.19 & 180.61 & 512.65 \\
\hline & $\mathrm{SD}$ & 44.08 & 5.76 & 1.83 & 24.95 & 76.59 \\
\hline \multirow[t]{5}{*}{2015} & 1 & 371.65 & 76.89 & 25.91 & 248.48 & 722.93 \\
\hline & 2 & 243.79 & 63.59 & 21.80 & 181.74 & 510.91 \\
\hline & 3 & 216.27 & 57.16 & 19.66 & 161.36 & 454.45 \\
\hline & Average & 277.24 & 65.88 & 22.45 & 197.19 & 562.76 \\
\hline & SD & 82.91 & 10.06 & 3.176 & 45.57 & 141.55 \\
\hline
\end{tabular}

Table 4. Comparison of aboveground biomass of mangrove forests in different region of the world

\begin{tabular}{|c|c|c|c|}
\hline Countries region & Species & $\operatorname{AGB}\left(\right.$ ton $\left.h^{-1}\right)$ & References \\
\hline \multicolumn{4}{|l|}{ Neotropical countries } \\
\hline Dominican & Rhizophora mangle & 233 & Sherman et al. (2003) \\
\hline Florida, USA & R. mangle forest & 56 & Ross et al. (2001) \\
\hline Mexico & R. mangle forest & 135 & Day et al. (1997) \\
\hline \multicolumn{4}{|l|}{ Subtropical countries } \\
\hline Japan (Okinawa) & R. mucronata & 108.1 & Suzuki and Tagawa (1983) \\
\hline Japan (Okinawa) & Bruguiera gymnorrhiza & 97.6 & Suzuki and Tagawa (1983) \\
\hline Japan (Okinawa) & Kandelia obovata & 80.5 & Khan et al. (2009) \\
\hline Hong Kong & Kandelia candel & 128.6 & Lee $(1990)$ \\
\hline \multicolumn{4}{|l|}{ Tropical countries } \\
\hline Malaysia (Matang) & R. apiculata & $270-460$ & Putz and Chan (1986) \\
\hline Kuala Selangor, Malaysia & B. parviflora & 144.47 & Hossein et al. (2008) \\
\hline Lawas, Malaysia & $R$. apiculata & 116.79 & Chandra et al. 2011 \\
\hline Thailand (Satun Southern) & Ceriops tagal & 92.2 & Komiyama et al. (2000) \\
\hline Bangladesh (Sundarbans) & Oligohaline mangrove & 154.8 & Kamaruzzaman et al. (2017) \\
\hline Indonesia (Halmahera) & B. gymnorrhiza forest & 436.4 & Tamai et al. (1986) \\
\hline Indonesia (Halmahera) & R. apiculata forest & 356.8 & Komiyama et al. (1988) \\
\hline Indonesia (Halmahera) & R. stylosa forest & 178.2 & Kusmana et al. (1992) \\
\hline Indonesia (East Sumatra) & B. sexangula stands & 76.0 & Kusmana et al. (1992) \\
\hline Indonesia (Southeast Sulawesi & Lumnitzera racemosa & 109.77 & Analuddin et al (2016b) \\
\hline \multirow[t]{2}{*}{ SE, protected area } & R. apiculata & 651.60 & Analuddin et al (2018) \\
\hline & R. mucronata & 232.11 & Analuddin et al (2018) \\
\hline \multirow[t]{2}{*}{ SE, unprotected area } & R. apiculata & 139.30 & Analuddin et al (2018) \\
\hline & R. mucronata & 189.32 & Analuddin et al (2018) \\
\hline $\begin{array}{l}\text { Southeast Sulawesi } \\
\text { (protected area) }\end{array}$ & R. stylosa & 562.76 & Current Study \\
\hline
\end{tabular}

These differences on aboveground biomass of various mangroves is due to differences in stand structure, climatic factors and habitat characteristics. However, higher biomass of mangroves might be indications of optimal habitat features, such as low salinity, high fertility and favorable climatic conditions (Saenger and Snedaker 1993). Therefore, the higher aboveground biomass of Rhizophora stylosa forest might be attributed to suitable conditions of soil structure, less anthropogenic disturbance, appropriate salinity and nutrient availability in the habitat.

\section{Trend in productivity of Rhizophora stylosa forest}

Table 5 shows the productivity of Rhizophora stylosa forest in Southeast Sulawesi. The yearly biomass increment of living $\Delta y^{\prime}$ of $R$. stylosa stands ranges from 36 to 61.34 ton $\mathrm{ha}^{-1}$ (average of 52.87 ton $\mathrm{ha}^{-1}$ ), while whole biomass increment of stand $\Delta y$ ranges from 34.79 to 58.34 ton ha ${ }^{-1}$ $\mathrm{yr}^{-1}$ (average of 50.09 ton $\mathrm{ha}^{-1} \mathrm{yr}^{-1}$ ). On the other hand, the standing dead biomass $D$ ranges from 1.40 to 4.20 ton ha $^{-1}$ $\mathrm{yr}^{-1}$ (average of 2.78 ton $\mathrm{ha}^{-1} \mathrm{yr}^{-1}$ ), but litterfall $\Delta L$ production ranges from 10.63 to 14.10 ton $\mathrm{ha}^{-1} \mathrm{yr}^{-1}$ (average of 12.00 ton $\left.\mathrm{ha}^{-1} \mathrm{yr}^{-1}\right)$. Aboveground $\Delta P_{\mathrm{n}}$ in $R$. stylosa stands 
ranges from 45.42 to 72.44 ton $\mathrm{ha}^{-1} \mathrm{yr}^{-1}$ (average of 62.09 ton $\mathrm{ha}^{-1} \mathrm{yr}^{-1}$ ). These trends indicate that productivity of $R$. stylosa stands varied across stands. Higher productivity of $R$. stylosa was found in stand 1, while it was the lower in stand 3 . These differences in productivity might be due to differences in tree size and stand density. The mean DBH of trees at stand 1 , stand 2 and stand 3 was $11.65 \mathrm{~cm}, 10.10$ $\mathrm{cm}$, and $9.43 \mathrm{~cm}$, respectively. However, tree density at stand 1 was 3500 individuals per hectare, while both at stand 2 and stand 3 it was 3800 individuals per hectare. Thus, high rate of net primary production of $R$. stylosa forest in the present study might be attributed to the tree size rather than tree density. Similar result was reported by Kamaruzzaman et al. (2017) that there was significant correlation between mean DBH and aboveground biomass of Sundarbans mangroves.

This study is the first report on the productivity of mangrove forests in the coral triangle areas. Comparison with the production values of mangrove forests from different places of the world (Table 6), showed that $\Delta y$, and $\Delta P_{\mathrm{n}}$ of $R$. stylosa forest in Southeast Sulawesi, Indonesia are much higher as compared with $\Delta y$ and $\Delta P_{\mathrm{n}}$ values of Kandelia obovata forest in Japan (Khan et al. 2009), Rhizophora mangle forest in Dominican (Sherman et al. 2003), $R$. mangle forest in Florida, USA (Ross et al. 2001), fringe mangrove forest in Australia (Alongi 2000) and Sundarbans mangrove forests in Bangladesh (Kamaruzaman et al. 2019). However, the $\Delta L$ of $R$. stylosa forest obtained in the present study showed higher value than those of other mangroves, except the $\Delta L$ of $R$. mangle mangrove growing in Florida, USA (Ross et al 2001). Our study revealed that higher $\Delta P_{\mathrm{n}}$ of $R$. stylosa forest was mostly contributed by $\Delta y$, while the ratio of $\Delta P_{\mathrm{n}}$ to $\Delta L$ was 5.17: 1 , indicating lower contribution of litterfall to the $\Delta P_{\mathrm{n}}$ of $R$. stylosa forest. Thus, results of this study are contrary to the assumptions of Kamaruzzaman et al. (2017) and Teas (1979) that the total net primary production for mangroves is three times larger than the amount of total litterfall.

\section{Trends of carbon sequestration}

Table 7 indicates the trends of carbon stock, carbon sequestration (net carbon budget, carbon gain, carbon input, and net carbon production) and carbon loss in Rhizophora stylosa forest growing in Southeast Sulawesi. The carbon stock ranges from 213.59 to 339.78 ton ha $^{-1}$ (average of 264.50 ton ha $\mathrm{ha}^{-1}$ ), which was higher in stand 1 than other stands. However, the carbon stock was about $49.26 \%$ in stem and $35.04 \%$ in prop root, while it was about $11.17 \%$ in branches/twigs and $3.99 \%$ in the leaf. The carbon stock in $R$. stylosa forest was much higher than that in mangrove at Peliat Island, Sumenep (10.80 ton/ha) as reported by Hidayath and Andriani (2019), as well as carbon stock of 115-225 ton/ha in many Asian coastal estuaries (IPCC 2006). These differences in carbon stock might be due to differences in biomass, tree size, etc. According to IPCC (2006), the concentration of carbon in vegetation depends on biomass, carbon absorption, soil fertility, plant diversity, and density. The mean annual of net carbon budget, carbon gain and carbon loss in $R$. stylosa forest was 23.54, 24.85 and 1.31 ton ha-1, respectively. Moreover, mean annual carbon input and net carbon production of $R$. stylosa forest was 5.64 and 29.18 ton $\mathrm{ha}^{-1}$. These trends indicate that this $R$. stylosa forest is high carbon sequestration, and is contributed to the global carbon budget.

Table 5. Trends in biomass increment of living trees $\Delta y^{\prime}$, whole biomass increment of stand $\Delta y$, standing dead biomass $D$, litterfall $\Delta L$ and net primary production $\Delta P_{\mathrm{n}}$ of Rhizophora stylosa forest in Southeast Sulawesi

\begin{tabular}{|c|c|c|c|c|c|}
\hline Stands & $\begin{array}{c}\Delta y^{\prime} \\
\left.\text { (ton } \mathrm{ha}^{-1} \mathrm{yr}^{-1}\right) \\
\end{array}$ & $\begin{array}{c}\Delta y \\
\left.\text { (ton } \mathrm{ha}^{-1} \mathrm{yr}^{-1}\right) \\
\end{array}$ & $\begin{array}{c}D \\
\left(\text { ton } \mathbf{h a}^{-1} \mathbf{y r}^{-1}\right) \\
\end{array}$ & $\begin{array}{c}\Delta L \\
\left(\text { ton } \mathrm{ha}^{-1} \mathrm{yr}^{-1}\right) \\
\end{array}$ & $\begin{array}{c}\Delta P_{\mathrm{n}} \\
\left(\text { ton } \mathrm{ha}^{-1} \mathrm{yr}^{-1}\right) \\
\end{array}$ \\
\hline 1 & 61.08 & 58.34 & 2.74 & 14.10 & 72.44 \\
\hline 2 & 61.34 & 57.14 & 4.20 & 11.27 & 68.42 \\
\hline 3 & 36.20 & 34.79 & 1.40 & 10.63 & 45.42 \\
\hline Average & 52.87 & 50.09 & 2.78 & 12.00 & 62.09 \\
\hline $\mathrm{SD}$ & 14.440 & 13.27 & 1.40 & 1.85 & 14.58 \\
\hline
\end{tabular}

Table 6. The comparison of whole biomass increment of stand $\Delta y$, litterfall $\Delta L$ and net primary production $\Delta P_{\mathrm{n}}$ of various mangrove species growing in different countries.

\begin{tabular}{|c|c|c|c|c|c|}
\hline Country & Mangroves & $\begin{array}{c}\Delta y \\
\left(\text { ton } \mathrm{ha}^{-1} \mathrm{yr}^{-1}\right)\end{array}$ & $\begin{array}{c}\Delta L \\
\left(\text { ton } \mathrm{ha}^{-1} \mathrm{yr}^{-1}\right)\end{array}$ & $\begin{array}{c}\Delta P_{\mathrm{n}} \\
\left(\text { ton } \mathrm{ha}^{-1} \mathrm{yr}^{-1}\right)\end{array}$ & References \\
\hline Okinawa, Japan & Kandelia obovata & $19.3-21.5$ & 10.6 & $29.9-31.2$ & Khan et al. (2009) \\
\hline Rep. Dominican & Rhizophora mangle & 9.7 & 11.4 & 19.7 & Sherman et al. (2003) \\
\hline Florida, USA & R. mangle & 13.9 & 12.2 & 26.61 & Ross et al. (2001) \\
\hline Australia & Mangrove fringe & 7.1 & - & 49.6 & Alongi (2000) \\
\hline Bangladesh & Mangrove of Sundarbans & - & 10.1 & 17.2 & Kamaruzzaman et al. (2019) \\
\hline Southeast Sulawesi, Indonesia & R. stylosa & 50.09 & 12.0 & 62.09 & This study \\
\hline
\end{tabular}


Table 7. Trends of the trends of carbon stock, carbon sequestration (net carbon budget, carbon gain, carbon input and net carbon production) and carbon loss in Rhizophora stylosa forest growing in Southeast Sulawesi.

\begin{tabular}{|c|c|c|c|c|c|c|}
\hline Stands & $\begin{array}{c}\text { C stock } \\
\left(\text { ton } \text { ha }^{-1}\right)\end{array}$ & $\begin{array}{l}\text { Net C budget } \\
\left(\text { ton } \mathbf{h a}^{-1} \mathbf{y r}^{-1}\right)\end{array}$ & $\begin{array}{c}\text { C gained } \\
\left(\text { ton } \mathbf{h a}^{-1} \mathbf{y r}^{-1}\right)\end{array}$ & $\begin{array}{c}\text { C loss } \\
\left(\text { ton } \mathrm{ha}^{-1} \mathrm{yr}^{-1}\right)\end{array}$ & $\begin{array}{c}\text { C input } \\
\left(\text { ton } \mathbf{h a}^{-1} \mathbf{y r}^{-1}\right)\end{array}$ & $\begin{array}{l}\text { Net C production } \\
\left(\text { ton } \mathbf{h a}^{-1} \mathbf{y r}^{-1}\right)\end{array}$ \\
\hline 1 & 339.78 & 27.42 & 28.71 & 1.29 & 6.63 & 34.05 \\
\hline 2 & 240.13 & 26.86 & 28.83 & 1.97 & 5.30 & 32.15 \\
\hline 3 & 213.59 & 16.35 & 17.01 & 0.66 & 5.00 & 21.35 \\
\hline Mean & 264.50 & 23.54 & 24.85 & 1.31 & 5.64 & 29.18 \\
\hline SD & 66.53 & 6.23 & 6.79 & 0.66 & 0.87 & 6.85 \\
\hline
\end{tabular}

Table 8. Trends of $\mathrm{CO}_{2}$ stock and $\mathrm{CO}_{2}$ sequestration in Rhizophora stylosa forest

\begin{tabular}{|c|c|c|c|c|c|}
\hline Stands & $\begin{array}{c}\mathrm{CO}_{2} \text { stored } \\
\left(\text { ton }^{-1}\right)\end{array}$ & $\begin{array}{c}\text { Net } \mathrm{CO}_{2} \text { Uptake } \\
\left(\text { ton } \mathbf{h a}^{-1} \mathbf{y r}^{-1}\right)\end{array}$ & $\begin{array}{l}\mathrm{CO}_{2} \text { gained } \\
\left(\text { ton } \mathrm{ha}^{-1} \mathrm{yr}^{-1}\right)\end{array}$ & 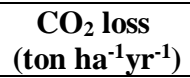 & $\begin{array}{c}\mathrm{CO}_{2} \text { input } \\
\text { (ton ha-1yr-1) }\end{array}$ \\
\hline 1 & 1245.84 & 100.54 & 105.26 & 4.72 & 24.30 \\
\hline 2 & 880.48 & 98.48 & 105.71 & 7.23 & 19.42 \\
\hline 3 & 783.17 & 59.95 & 62.38 & 2.41 & 18.32 \\
\hline Mean & 969.83 & 86.33 & 91.12 & 4.79 & 20.68 \\
\hline $\mathrm{SD}$ & 243.94 & 22.86 & 24.89 & 2.41 & 3.18 \\
\hline
\end{tabular}

Table 8 shows trends of $\mathrm{CO}_{2}$ stock and $\mathrm{CO}_{2}$ sequestration in Rhizophora stylosa forest. The total $\mathrm{CO}_{2}$ stored in mangrove stands ranges from 783.17 to 1245.84 ton $\mathrm{ha}^{-1}$ (average of 969.83 ton $\mathrm{ha}^{-1}$ ). The yearly net $\mathrm{CO}_{2}$ uptake by Rhizophora stylosa forest ranges from 59.95 to 100.54 ton $\mathrm{ha}^{-1}$, while annual $\mathrm{CO}_{2}$ loss due to trees death ranges from 2.41 to 7.23 ton ha $\mathrm{ha}^{-1}$ (average of 1.31 ton $\mathrm{ha}^{-1}$ ). Annual $\mathrm{CO}_{2}$ gained by living $R$. stylosa trees ranges from 62.38 to 105.26 ton $\mathrm{ha}^{-1}$ (average of 4.79 ton ha ${ }^{-1}$ ), and annual $\mathrm{CO}_{2}$ input by litterfall in $R$. stylosa forest range 18.32 to 24.30 ton $\mathrm{ha}^{-1}$ (average of 20.86 ton $^{-1}$ ). The concentrations of $\mathrm{C}$ and $\mathrm{CO}_{2}$ in $R$. stylosa forest were about $49 \%$ and $35 \%$ stored in stems and prop root parts, respectively. Results of this study differ Hidayah and Andriani (2019) according to which the $\mathrm{C}$ and $\mathrm{CO}_{2}$ concentrations in stems of mangroves of Peliat Island was about $76 \%$. The higher carbon content in mangrove trees might be due to a high concentration of xylem and lignin in their stem and prop root tissues. Meanwhile, Hidayah and Andriani (2019) mentioned that with aging, the stems of trees tend to improve the cellulose substances and lignin. Krauss and Ball (2013) found that carbon content in cellulose and lignin is approximately $44.44 \%$ and $67.50 \%$, respectively. Moreover, Effendi and Rusmana (2017) argued that mangrove ecosystems are capable of higher $\mathrm{CO}_{2}$ absorption than terrestrial plants. In addition, Gilman et al. (2008) stated that the photosynthesis ability of mangroves is dependent on leaves capacity to absorb atmospheric $\mathrm{CO}_{2}$, which in turn depends on the stomatal conductance and the enzymatic activity.

In conclusion, this study shows that although there are variations in suitability of independent variables for estimation of partial and whole aboveground biomass of Rhizophora stylosa forest, $\mathrm{DBH}$ is the best predictor for estimating the partial and whole biomass of $R$. stylosa trees, due to its easy measurement in the field. This study also confirms the high accumulation of aboveground biomass (562.76 ton $\left.\mathrm{ha}^{-1} \mathrm{yr}^{-1}\right)$ and productivity (62.09 ton $\mathrm{ha}^{-1} \mathrm{yr}^{-1}$ ) of $R$. stylosa forest in Southeast Sulawesi, which indicates the significant contribution of this forest to the global carbon and nutrients budget. Moreover, the higher carbon sequestration and $\mathrm{CO}_{2}$ uptake in $R$. stylosa forest indicate its significant role in the global carbon accumulation and reducing atmospheric $\mathrm{CO}_{2}$.

\section{ACKNOWLEDGEMENTS}

This research was supported by the Ministry of Research, Technology and Higher Education, Republic of Indonesia with grant nos. 0263/E5/2014, 0100/E5.1/PE/2015, and T/140/E3/RA.00/2019, in collaboration with Tokyo Institute of Technology, Japan. We also like to thank Rector of Universitas Halu Oleo Kendari, Indonesia and President of Tokyo Tech, Japan.

\section{REFERENCES}

Alongi DM, Dixon P. 2000. Mangrove primary production and above- and below-ground biomass in Sawi Bay, southern Thailand. Phuket Mar Biol Center Spec Publ 22: 31-38

Analuddin K, Jamili, Septiana A, Harlis Wd, Sahidin I, Usman R, Saban R, Sharma S, Nadaoka K. 2016a. Blue carbon stock and green tea potential in mangroves of coral triangle eco-region, Southeast Sulawesi, Indonesia. Inter. J Environ 1: 125-132.

Analuddin K, Jamili, Septiana A, Raya R, Rahim S. 2013. The spatial trends in the structural characteristics of mangrove forest at the Rawa Aopa Watumohai National Park, Southeast Sulawesi, Indonesia. Intl J Plant Sci 4 (8): 214-221

Analuddin K, Jamili, Septiana A, Raya R, Rianse R, Sahidin I, Rahim S, Alfirman, Sharma S, Nadaoka K. 2018. Trends in allometric models and aboveground biomass of Rhizophoraceae mangrove family at the coral triangle ecoregion, Southeast Sulawesi, Indonesia. J Sus For 37 (7): 691-711. 
Analuddin K, Jamili, Septiana A, Raya R, Rianse R, Sahidin I, Rahim S, Alfirman, Sharma S, Nadaoka K. 2016b. Allometric models and aboveground biomass of mangrove Lumnitzera racemosa Wild. Forest at Rawa Aopa Watumohai National Park, Southeast Sulawesi, Indonesia. For Sci Tech 12 (1): 43-50

Analuddin K, Septiana A, Nasaruddin, Yusuf S, Sharma S. 2019 Mangrove Fruit Bioprospecting: Nutritional and Antioxidant Potentia as a Food Source for Coastal Communities in the Rawa Aopa Watumohai National Park, Southeast Sulawesi, Indonesia. Intl J Fruits Sci 19 (4): 423-436.

Analuddin K, Sharma S, Jamili, Septiana, Sahidin I, Usman R. and Nadaoka, K. 2017. Heavy metal bioaccumulation in mangrove ecosystem at the coral triangle ecoregion, Southeast Sulawesi, Indonesia. Mar Bull Pollut 125: 472-480.

Analuddin K, Suwa R, Hagihara A (2009) The self-thinning process in mangrove Kandelia obovata Young stands. J Plant Res 122 (1): 53-59

Briggs JC. 2005a. The marine East Indies: diversity and speciation. J Biogeogr 32: 1517-1522

Brown S. 1997. Estimating biomass and biomass change of tropical forest: A primer, 1st ed. Food and Agriculture Organization, Rome.

Chandra IA, Seca G, Abu-Hena MK. 2011. Aboveground biomass production of Rhizophora apiculata Blume in Sarawak mangrove forest. Amer J Agric Biol Sci 6 (4): 469-474

Clough BF, Dixon P, Dalhaus O. 1997. Allometric relationships for estimating biomass in multi-stemmed mangrove trees. Aust J Bot 45: 1023-1031

Clough BF, Scott K. 1989. Allometric relationships for estimating aboveground biomass in six mangrove species. For Ecol Manag 27: 117-127.

Clough BF. 1992. Tropical Mangrove ecosystem, coastal and estuarine studies 41. In: Robertson AI, Alongi DM (eds.). Primary productivity and growth of mangrove forests. American Geophysical Union, Washington, DC.

Comley BWT, McGuinness KA. 2005. Above- and below-ground biomass, and allometry of four common northern Australian mangroves. Aust J Bot 53: 431-436.

Conacher CA, O’Brien C, Horrocko JL, Kenyon RK. 1996. Litter production and accumulation in stressed mangrove communities in the Embley river estuary, Northeastern Gulf of Carpentaria, Australia. Mar Fresh Resour 47: 737-743.

Day J, Conne JW, Ley-Lou F, Day R, Navarro A. 1997. The productivity and composition of mangrove forests, Laguna de Terminos, Mexico. Aquat Bot 27: 267-284

Deshar R, Sharma S, Hoque ATMR, Mouctara K, Hagihara A. 2012. Selfthinning of leaf, wood and aboveground in overcrowded mangrove Bruguiera gymnorrhiza stands in Okinawa Island, Japan. Procedia Environ Sci 13: 982-993.

Effendi R, Rusmana I. 2017. Estimation of stock and carbon absorption of mangroves in Tallo River Makasar. J For Sci 11: 19-28.

Fromard F, Puig H, Mougin E, Marty G, Betoulle JL, Cadamuro L. 1998 Structure above-ground biomass and dynamics of mangrove ecosystems: new data from French Guiana. Oecologia 115: 39-53.

Gilman EL, Ellison J, Duke NC, Field C. 2008. Threats to mangroves from climate change and adaptation options. Aqua Bot 89: 237-250

Golley FB, Mcginnis JT, Clements RG, Child GI, Duever MJ. 1975. Mineral Cycling in a Tropical Moist Forest Ecosystem. Georgia University Press, Athens.

Hidayah Z, Andriani L. 2019. Carbon Stock Analysis of Mangrove Ecosystems in Paliat Island Sumenep East Java. IOP Conf Ser: Earth Environ Sci 276: 012034. DOI: 10.1088/1755-1315/276/1/012034.

Hoque MM, Kamal ABH, Idris MH, Ahmed OH, Hoque ATMR, Billah MdM. 2015. Litterfall production in a tropical mangrove of Sarawak, Malaysia. Zool Ecol 25 ( 2): 157-165.

Hossein M, Othman S, Bujang JS, Kusnan M. 2008. Net primary production of Bruguierra parviflora (Wight \& Arn.). For Ecol Manag 255: 179-182.

IPCC 2006. IPCC Guidelines for National Greenhouse Gas Inventories. Prepared by the National Greenhouse Gas Inventories Programme Institute For Global Environmental Strategies, Japan.

Kamaruzaman Md, Ahmed S, Osawa A 2017. Biomass and net primary productivity of mangrove communities along the Oligohaline zone of Sundarbans, Bangladesh. Forest Ecosyst 4: 16. DOI 10.1186/s40663017-0104-0.

Ketterings QM, Noordwijk CMY, Ambagau R, Palm CA. 2001. Reducing uncertainty in the use of allometric biomass equations for predicting above-ground tree biomass in mixed secondary forests. Fort Ecol Manag 146: 199-209.

Khan MNI, Shil MC, Azad MS, Sadath MN, Feroz S, Mollick AS. 2018. Allometric relationships of stem volume and stand level carbon stocks at varying stand density in Swietenia macrophylla King plantations, Bangladesh. For Ecol Manag 430: 639-648.

Khan MNI, Suwa R, Hagihara A. 2009. Biomass and aboveground net primary production in a subtropical mangrove stand of Kandelia obovata (S., L.)Yong at Manko Wetland, Okinawa, Japan. Wetlands Ecol Manag 17: 585-599

Kira T, Shidei T. 1967. Primary production and turnover of organic matter in different forest ecosystems in western pacific region. Jpn J Ecol 17 (2): $70-87$.

Komiyama A, Moriya H, PrawiroatmodjoS, Toma T, Ogino K. 1988. Forest primary productivity. In: Ogino K, Chihara M (eds.), Biological System of Mangrove. Ehime University, Ehime, Japan.

Komiyama A, Ong JE, Poungparn S. 2008 Allometry, biomass and productivity of mangrove forests: A review. J Aquat Bot 89: 128-137

Komiyama A, Poungparn S, Kato S. 2000. Common allometric equations for estimating the tree biomass of mangroves. J Trop Ecol 21: 471477.

Komiyama A, Poungparn S, Kato S. 2005. Common allometric equations for estimating the tree weight of mangroves. J Tropic Ecol 21: 471477.

Krauss KW, Ball MC. 2013. On the Halophytic Nature of Mangroves. Trees. 27: 7-11.

Kristensen E., Suraswadi P. 2002. Carbon, nitrogen and phosphorus dynamics in creek water of a Southeast Asian mangrove forest. Hydrobiologia 474: 197-211.

Kusmana C, Sabiham S, Abe K, Watanabe H. 1992. An estimation of above-ground tree biomass of a mangrove forest in East Sumatra, Indonesia. Tropics 1: 243-257

Lee SY. 1990. Primary productivity and particulate organic matter flow in an estuarine mangrove-wetland in Hong Kong. Mar Biol 106: 453463.

Mahmood H, Saberi O, Jaber-Sidik B, Misri K, Rajgopal S. 2004. Allometric Relationship for Estimating Above and Below Ground Biomass of Saplings and Tress of Bruguiera parviflora (White and Arnold). Mal App Biol 33 (1): 37-45.

Mahmood I. 2012. Prediction of clearance and volume of distribution in the obese from normal weight subjects: An allometric approach. Clin Pharmacokinet 51 (8): 527-542.

Ong JE, Gong WK, Wong CH. 2004. Allometry and partitioning of the mangrove, Rhizophora apiculata Blume. For Ecol Manag 188: 395408.

Putz F, Chan HT. 1986. Tree growth, dynamics, and productivity in a mature mangrove forest in Malaysia.For Ecol Manag 17: 211-230

Ross MS, Ruiz PL, Telesnicki GJ, Meeder JF. 2001. Estimating aboveground biomass and production in mangrove communities of Biscayne National Park, Florida (USA). Wetlands Ecol Manag 9: $27-$ 37

Sanger P, Snedaker SC. 1993. Pantropical trends in mangrove aboveground biomass and annual litterfall. Oecologia 96: 293-299

Septiana A, Jamili, Harlis Wd, Analuddin K. 2016. Mangroves bioprospecting: Antioxidant source and habitat of endemic animal Buballus sp. in Rawa Aopa Watumohai National Park, Southeast Sulawesi, Indonesia. Malay App Bio 45 (1): 23-34.

Sherman RE, Fahey TJ, Martinez P. 2003. Spatial patterns of biomass and aboveground net primary productivity in a mangrove ecosystem in the Dominican Republic. Ecosystem 6: 384-398.

Siddique MRH, Mahmood H, Chowdhury MRK. 2012. Allometric relationship for estimating above-ground biomass of Aegialitis rotundifolia Roxb. of Sundarbans mangrove forest, in Bangladesh. J For Res 23 (1): 23-28.

Spalding M, Kainuma M, Collins L. 2010. World atlas of mangroves. Earthscan, London, UK

Steinke TD, Ward CJ, Rajh A. 1995. Forest structure and biomass in Mgeni estuary, South Africa. Hydrobiologia 295: 159-165.

Suzuki E, Tagawa E. 1983. Biomass of a mangrove forest and a sedge marsh on Ishigaki Island, South Japan. Jpn J Ecol 33: 231-234

Tamai S, Nakasuga T, Tabuchi R, Ogino K. 1986. Standing biomass of mangrove forests in southern Thailand. J Jpn For Soc 68: 384-388

Teas HJ. 1979. Silviculture with saline water. In: Hollander A, Aller JC Epstein E, Pietro AS, Zaborsky OR (eds.). The baseline concept. Plenum Press, New York. 
Twilley RR. 1995. Properties of mangrove ecosystems related to the energy signature of coastal environments. In: Hall CAS (ed.) Maximum Power: The Idea and Applications of HT Odum. University of Colorado Press, Colorado.
Twilley RR. 1998. Mangroves wetlands. Southern forested wetlands Ecol Management. Messina M, Connertj WH (eds.). CRC Press, Boca Raton, FL.

Twilley, RR, Chen R, Hargis T. 1992. Carbon sinks in mangroves and their implication to carbon budget of tropical ecosystems. Water Air Soil Pollut 64: 265-288. 